\title{
Was die Afskeiding onder ds F Lion Cachet van 1865/6 "sondige verskeurdheid?
}

\section{H G V D WESTHUIZEN}

Op hierdie vraag antwoord die Hervormde Kerk se navorsers gewoonlik ja en die Ned Gereformeerde Kerk se navorsers nee. Eensydigheid van beide kante het oor die loop van jare 'n polemiek tot gevolg "waarin die een kerk die ander sy egtheid, geskiedkundige voorrang, besitreg of selfs bestaansreg in hierdie land wil betwis." 1

Die feit is dat die Ned Geref Kerk in Transvaal vir die eerste keer georganiseer is tot ' $n$ sinode in die jare $1865 / 6 .{ }^{2}$ Om die vraag te kan beantwoord of hierdie organisering van die Ned Gereformeerde Kerk ' $n$ aanvaarbare afskeiding of ' $n$ sondige verskeurdheid was, of geen van beide, sal ons die figuur van ds F Lion Cachet deeglik in die oog kry. Buitestaanders buite die polemiek oor die 1865/6 gebeure, aanvaar immers dat Cachet "die spil was waarom die ontstaan van die Ned Geref Kerk in Transvaal gedraai het."3

Die dryfvere wat Cachet aangee tot sy optrede in hierdie jare, kan ten opsigte van ons onderwerp gereduseer word tot die vername vier. Die Hervormde Kerk sou afwykend wees wat sy naam, belydenis, leer en praktyk betref. ${ }^{4}$ Ons sal eers kortliks hierdie dryfvere nagaan om so sy optrede te probeer verstaan. Daarna sal ons kan besluit hoe sy optrede gekarakteriseer moet word.

\section{Die Naam}

Navorsers is dit blykbaar eens dat die naamstryd van die twee betrokke kerke histories net tot by Cachet loop. Hy geniet die vaderskap van die naamkwessie. ${ }^{5}$ Sedert Cachet is daar egter 'n steeds voortgaande stryd . . . tussen kerkmanne - oor die naam van hulle kerk!"6 Hervormde navorsers hou vol dat die naam "Hervormd" histories in die Transvaal verder teruggaan as 1859 of 1855 of 1853 of 1841, selfs tot baie vroeër in sowel die Transvaal as die Kaap, en ander provinsies, en in Holland. Die Ned Gereformeerde navorsers wil hoofsaaklik dat slegs die naam "Gereformeerd" oudste historiese gronde geniet.

Voordat ons die hoofargumente van Ned Gereformeerde en Hervormde kante aandui, is dit goed om te onthou dat "al die baie name vir die kerk die letsels (is) wat die kerk opgedoen het in ons hande ... Merkwaardig kry ons by Calvyn wel die indruk dat hy 'n naam het vir die gestalte van die kerk wat hy verwerp - Kerk van 
Rome - maar vir die kerk waaraan hy vashou het hy geen naam nie."7 In die geskiedenis van die onderhawige naamkwessie, ${ }^{8}$ bemerk ons ook dat waar die name Hervormd en Gereformeerd sedert die Hervorming algemene beskrywing van die kerk was, wat afwisselend en voetstoots gebruik is, word dit sedert Cachet in ons land onafwisselbare kerkname in die volle sin van die woord. Die onafwisselbare vaslegging van die twee name Ned Hervormd en Ned Gereformeerd is iets wat aan Cachet te danke is. Hy het immers self die vere-gelykenis vertel om die noodsaaklikheid van naamsvasstelling te beklemtoon. Die burgers van 'n sekere republiek het gewoonlik vere op die hoed gedra, volstruisvere of kraanvoëlvere soos elkeen wil. Toe hierdie burgers egter in twee partye verdeel, het die een party uitsluitlik volstruisvere en die ander kraanvoëlvere gedra. Nou het die veer die party aangedui. "Men ziet hieruit dat wat op zich zelven onverschillig is, door de omstandighede van het grootste gewig worden kan. Zoo is het met den naam der Kerk. Het was vroeger geheel en al onverschillig of de Kerk genoemd werd Gereformeerd of Hervormd daar de Kerk onvoorwaardelyk vasthield aan de Formulieren van Eenigheid; doch in het begin dezer eeuw werd de Kerk in Holland een nieuwe Constitutie opgedrongen, en werd bepaald dat de predikanten zich niet meer zoo stipt aan de formulieren behoefden te houden, en de Kerk werd genoemd by uitsluiting de Hervormde Kerk . . . Er ontstond eene verdeeling. Het gedeelte der Kerk dat de Formulieren niet strengelyk wilde handhaven, bleef zich noemen Hervormde Kerk, terwyl de gedeelte dat de Formuliere wel gestreng bleef vasthouden, zich bleef noemen Gereformeerde Kerk, zoodat nu in Holland Gereformeerde Kerk gelyk staat met vasthouden der formulieren, en de Hervormde Kerk met niet vasthouden der formulieren ... Is het wonder dat dit de vrees geboren worden deed of niet misschien met den naam Hervormd ook de ongereformeerde liberale stellingen der Kerk in Holland hier waren aangenomen, en dat het wenschelyk werd geacht, dat het ook uit den naam der Kerk ondubbelzinnig blyken sou dat zy in den volsten zin des woord Gereformeerd was."

Cachet se stelling: "het was vroeger geheel en al onverschillig of de Kerk genoemd werd Gereformeerd of Hervormd" word gestaaf deur die historiese feite.

Teen die helfte van die 16de eeu het die Hervormers in Holland hulle kerk dikwels Gereformeerde kerk begin noem, wat'n vernederlandsde vorm van die Franse "L'Eglise réformée" is - soos Calvyn se Genéve gemeente die spraakgebruik ingevoer het. ${ }^{10} \mathrm{Vir}$ twee eeue lank, sedert omtrent 1550 is ook die beskrywing hervormd naas gereformeerd vir die kerk in Nederland gebruik. ${ }^{11}$

Toe was die "benaming hervormd en gereformeerd ... nie eiename nie, maar benamings waarmee uitgedruk is dat die religie van die kerk gereformeer is, die godsdiens hervorm is, gesuiwer van 
die pouslike dwaalleer. In die agtiende eeu is in Nederland die naam hervormd meer en meer bo die naam gereformeerd gebruik, en toe na die skeiding van kerk en staat in 1795 verskillende geloofsgemeenskappe as kerke erken is, moes die ou historiese kerk van Nederland ' $n$ eie naam hê, en dit was Hervormd."12

Dis vanselfsprekend dat beide beskrywings van die kerk, hervormd en gereformeerd, tydens en na ons volksplanting in gebruik sou wees, soos in die stamland. Jan van Riebeeck se gebed spreek dan ook van die "gereformeerde Christelijke Lere."13 Op 23 Augustus 1665 het die eerste aanleg van 'n "Kerken-boek" begin. Daarin is met die bevestiging van die eerste kerkraad, aangeteken: "wij onderschrevenen, Abr Schut, ouderling, en Johan Reinierszen, diaken ... die op den ... in dienst bevestigt zijn, erkennen met dezen de belijdenissen der Gereformeerde Kerke voor goed en met het Woord Gods overeenstaande"14 Die oudste attestaat in die Kaapse Kerkargief, dié van Hermanus Bosman, 24 Desember 1705 lui dat: "Hermanus Bosman lidmaat is van de ware Gereformeerde Christelijke Kercke $\ldots{ }^{15}$ Voorbeelde vir die gebruik van gereformeerd sedert 1652 tot 1800 is baie en maklik te vind in die kerklike dokumente van daardie tyd.

Maar so is daar ook voorbeelde te vind vir die gebruik van hervormd in daardie tyd. Die oudste gedrukte preek in ons land, oor Jesaja 45:1-8, gehou op 16 Januarie 1743 aan die Kaap, verskyn met die toestemming dat die preek nie in stryd is met die leer van die "Herformde Kerk" nie. ${ }^{16}$ Aan die einde van hierdie periode 1652-1800, was die benaming hervormd baie gebruiklik. So noem die kerkraad van Kaapstad op 4 April 1803 homself "Kerkenraad der Hervormde gemeente deeser steede." ${ }^{17}$ Die Kerkorde van De Mist is in 1804 opgestel met die naam Hervormd. "'n Vaste benaming was nou nodig want De Mist het die beginsel van skeiding van kerk en staat soos dit in Nederland gegeld het, in Suid-Afrika deurgevoer en alle 'Kerk-genootschappen' gelykgestel. ${ }^{18}$

Nou kan ons die vraag stel waarom hervormd voorrang bo gereformeerd teen die einde van die 18de en die begin van die 19de eeu in Nederland en Suid-Afrika geniet het?

Eensdeel word geantwoord: "Omdat 'Hervormd" 'n suiwer Nederlandse woord is, het baie mense waarskynlik ook daaraan die voorkeur begin gee, hoewel dit van presies dieselfde betekenis as 'Gereformeerd' is. Hoe dit ook sy, aan die begin van die negentiende eeu, in 1816, het Koning Willem I van Nederland 'n nuwe kerkorde opgestel en daarin is "Hervormd" as die naam van die kerk vasgelê."'19

'n Verdere verklaring vir die toenemende gebruik van hervormd word gegee in die liberalisering van die kerk. Omdat hervormd die plaaslike woord is en daarom jonger as die vernederlandsde maar oorspronklik Franse gereformeerd, het dit bruikbaarder geword soos 
die kerk meer modern-liberaal in die betrokke tydperk geword het. In hierdie tyd is die vasstelling van die naam en wel as Hervormde Kerk, 'n voldonge feit. ${ }^{20}$

Soos dit in die moederland gesteld was, so ook in Suid-Afrika. Ons kry sedert 1804 die naam hervormd offisieel en oorheersend tot 1834. "Maar vanaf die Sinode van 1834 begin die naam gereformeerd meer as tevore gebruik word." ${ }^{21}$ Gedurende die hele tydperk 1804 tot 1834 is gereformeerd egter ook in die kerklike taal gebruik. ${ }^{22}$

Waarskynlik het die terugkeer van die veelvuldige gebruik van gereformeerd ná 1834 te doen met die reaksie in ons land teen die liberalisme. In 1842 word volgens sinodebesluit die benaming hervormd in offisiële kerklike stukke vervang met gereformeerd. ${ }^{23}$ Dit kan ook wees dat die Skotse predikante in die Kaap wou breek met Nederland en dat gereformeerd daarom onder hulle invloed, hervormd vervang het. ${ }^{24}$

Nogtans was hervormd buite Transvaal dikwels gebruik ook ná 1842. "In Kaapstad self is die gemeente tot in 1871 nog op die doopseëls Ned Hervormd genoem, en tot in 1885 nog is op die aannemingskaarte Hervormde Kerk Kaapstad, gedruk. In die formulier wat die nuwe predikante . . . moet onderteken, is in die Kaapse kerk tot in 1873 nog Hervormd genoem." ${ }^{25}$ Ten spyte van Natal se anneksasie in 1843 en die Vrystaatse anneksasie in 1848 deur die Kaapse Engelse owerheid, en die stigting van die Ring van Transgariep deur die Kaapse Sinodale Kommissie op 4 September 1850 , wat genoemde twee provinsies sou moes omvat, ${ }^{26}$ het die naam hervormd dikwels steeds voortgeleef. Tot in 1842 word die Bodenstein-kinders as lidmate van die Hervormde Kerk in Natal in hulle geslagsregister aangedui. ${ }^{27}$ "So het $\mathrm{NJ}$ Boshof, die latere Vrystaatse Staatspresident in sy toespraak nog die naam Hervormd gebruik, en die verslag van hierdie verrigtings (die tweede eeufees van Suid-Afrika) het as opskrif: 'Feestviering gehouden in de Nederduitsche Hervormde Kerk te Natal op Dinsdag avond 6 April 1852'." ${ }^{\prime 28}$ Toe die Vrystaatse grondwet in 1854 opgestel is, is die kerk Nederduitsch Hervormd genoem. Eers in 1867 is hervormd hier verander na gereformeerd. Maar in die kerkwet se aanhef het hervormd voortgeleef tot in $1956 !^{29}$

Gedurende die periode dat hervormd nog die oorheersende kerknaam aan die Kaap was, het die Groot Trek in 1836 plaasgevind. Dit is vanselfsprekend dat hulle beide benaminge sou gebruik. Daar is dan ook baie bewyse dat hulle gereformeerd gebruik het. ${ }^{30}$ Daar is net so baie bewyse dat hulle hervormd gebruik het. ${ }^{31}$ Die 1837 Sinode byvoorbeeld wat onder andere handel oor die oorvloed predikante in die Kaap, die afkeur van die Groot Trek, formulier, ensovoorts hanteer die naam hervormd spontaan en sonder emosie. $^{32}$

Om dit te regverdig dat Cachet hervormd verwerp en gerefor- 
meerd aanvaar, word ' $n$ historiese vooropset daargestel dat die naam hervormd aan die Kaap geheel ontbreek het, tot dit vanweë Nederland se liberale invloed vir die eerste keer in 1775 aan die Kaap gebruik is ${ }^{33}$ Verder word hierdie opset uitgebou deur te suggereer dat, met die uitsondering van 1841 se kollektelysie van Potchefstroom die Voortrekkers van 1836 af nie die woord hervormd gebruik het nie. ${ }^{34}$ Die woord hervormd in Transvaal sou dan eers in 1855 van die Hollander Stuart, wat die ZAR se ontwerp grondwet opgestel het, afkomstig wees. ${ }^{35}$ Ds Dirk v d Hoff, 'n Hollander, sou aanvanklik in 1853 ook hervormd gebesig het, totdat hy by die Voortrekkers die regte woord gereformeerd geleer het! ${ }^{36}$ Hierna sou Ds $\mathrm{v}$ d Hoff in 1859 weer gereformeerd laat vaar het ten gunste van hervormd omdat die kerk onderskei moes word van die nuut gestigte Gereformeerde Kerk en ook omdat die staat onder Hollandse invloed die staatskerk hervormd genoem het in $1855 .{ }^{37}$ Hierdie opset leen hom tot die volgende stelling: “. . . dat daar tussen die gebruikmaking van die naam 'Hervormd' in die Kaapkolonie tot 1842 en die invoering van hierdie naam in die Transvaal in 1855 nie die minste verband bestaan nie." ${ }^{\prime 38}$ Met ander woorde die naam hervormd vir die Transvaalse kerk sou uitsluitlik onder die Nederlandse liberale invloed wees. Dan sou Cachet waarskynlik volkome grond hê vir sy naam-motief in sy optrede.

Hoe gerieflik hierdie voorgestelde historiese opset ookal is, bly dit bots met die historiese feite, soos dit nagegaan kan word in die reeds aangehaalde Engelbrecht-Scholtz kontrovers.

Aangesien die benaming hervormd benewens gereformeerd deurentyd deur die Voortrekkers gebruik is, staan hervormd nie per se in ons kerkgeskiedenis vir liberaal nie. Dit was Cachet wat hervormd hierdie stempel kom gee het. ${ }^{39} \mathrm{Hy}$ het die kraanvoëlveerdraers (Hervormde Kerk in Transvaal) liberaal genoem en die volstruisveerdraers (Ned Gereformeerde Kerk in die Kaap) ortodoks. Miskien sou ' $n$ mens hom nie kon verkwalik het nie omdat hy in 1858 eers met die Kaap kennis maak, ná sy koms uit Holland en dus geen kennis dra van die kerklike agtergrond van die Voortrekkers nie. In daardie stadium weet hy dat hervormd in Nederland vir liberaalveerdraers staan en gereformeerd vir ortodoksveerdraers. In die Kaap self vind hy ook die naam offisieel onder die ortodokse veer, gereformeerd; alhoewel onder andere die bevestigingsformulier nog van Hervormde Kerk gepraat het, waaronder hy ook toegelaat is. ${ }^{40}$

Sy optrede in 1865/6 waarby die naam-motief 'n groot rol speel, getuig egter nie soseer van eerlike onkunde nie, maar van eiewysheid. Hy wou finansiële voordeel trek vanuit Utrecht uit die ZAR en het daarom dikwels skuilgegaan onder hervormd, maar verder wou hy breek met die hervormde staatskerk. ${ }^{41}$ Miskien kan 'n mens begrip hê vir sy afkeuring van die staatskerk-gedagte omdat hy sy teologiese opleiding wat vir sendelinge bedoel is, ontvang het in die 
Free Church of Scotland. Toe hy in 1849 op veertien jarige ouderdom Christen word, ${ }^{42}$ het die Skotse Protestantse kerk reeds ses jaar, sedert 1843, in twee geskeur. Die Free Church of Scotland, was vry van die staat "en aanvanklik ook van liberale invloede wat in die ou staatskerk steeds sterker geword het. ${ }^{43}$ In Holland het hy verder die agtergrond opgedoen dat die kerk terwyl hy die naam hervormd dra, sterk beweeg het in die liberale rigting. In 1816 het die sinode van die Hervormde Kerk op bevel van die koning vergader. Daar is ' $n$ "Algemeen Reglement" opgestel waar in artikel 9 onder andere bepaal word: "De zorg voor de belangen, zoo van het Christendom in het algemeen, als van de Hervormde kerk in het bijzonder, de handhaving harer leer ...44" Die staat en die kerk, in die noue verbintenis, het egter nie die leer in suiwerheid gekoester nie. ${ }^{45}$ In die Transvaal wou die Voortrekkers geen neutrale staat hê nie. "Geen skeiding van Kerk en Staat nie, maar wel'n onderskeiding tussen die twee. Hulle het op die beginsel van artikel 36 van die Nederlandse Geloofsbelydenis gestaan in sy onveranderde vorm en nie soos dit later in Nederland onder Neo-Calvinistiese invloed gewysig is nie." 46

Cachet het hom dit druk gemaak om soos in Holland, ook in die Transvaal hervormd as verkeerde vere aan te dui. ${ }^{47}$ Die feite dui daarop, tenspyte van Cachet se ontkennings ${ }^{48}$ dat al sou alle ander dinge in verband met die Transvaalse Kerk vir Cachet aanvaarbaar wees, maar die naam sou hervormd bly, dan skei hy nog af. Hy het immers, soos sekere navolgers, daarop gehamer dat die naam in Transvaal verander is. ${ }^{49}$ Die naam was "ons eerste bezwaar . . . Maar as die naam verander was, dan is dit tog nog die ou voël, net met veranderde vere. Dan gaan jy nie die voël doodmaak nie. Dan sou 'n mens in Reformatoriese gees verwag dat miskien alles gedoen sou word om die naam weer terug te verander, buiten om dit deur afskeiding of skeuring te doen. Selfs by die Reformatore het dit nooit om afskeiding of skeuring gegaan van die kerk wat Rooms-Katoliek genoem is nie. ${ }^{51}$

Omdat Cachet wat die naam-motief betref dus die één onreformatoriese weg gekies het vir sy optrede, was sy kerkvorming in hierdie verband niks minder as sondige verskeuring nie.

Ten slotte moet onder hierdie afdeling vermeld word dat die Hervormde Kerk in Transvaal in 1879 hom volkome vergewis het dat hy tereg die naam Ned Hervormd dra. ${ }^{52}$

\section{Belydenis}

Op 26 Junie 1865 het die Uitvoerende Raad van die ZAR indirek en die Kommissie van die Algemene Kerkvergadering direk, op Rustenburg probeer om Cachet se Utrecht gemeente in te lyf by die staatskerk sodat aan Cachet se versoek tot staatssalaris voldoen kon 
word. ${ }^{33}$ Op hierdie vergadering onder voorsitterskap van ds Smits van Rustenburg en met ds Van Warmelo van Noord Transvaal as skriba, het Cachet ook sy tweede beswaar gestel - oor die verwaarlosing van die belydenis. ${ }^{54}$ Sy belydenis-beswaar het in momentum toegeneem op die Algemene Kerkvergadering te Pretoria op 20 November 1865, waar hy nog steeds 'n buitestaander was. ${ }^{55}$

Sy beswaar in hierdie verband formuleer hy self soos volg: "Omdat de Hervormde Kerk door hare algemeene Kerkvergadering te Pretoria - November 1.1. - duidelyk verklaard heeft dat hare leeraren niet gebonden zyn in de leer door de Formulieren van Eenigheid der Gereformeerde Kerk." ${ }^{56}$ Daarom besluit Cachet: "Om lid te zyn der liberale Herv Kerk moet gy eerst ontrouw worden aan uwe belydenis belofte. ${ }^{57}$

Oor hoever die liberale gees ingevreet het in Holland en in die Kaapse Ned Gereformeerde Kerk in hierdie tyd, is daar volkome klaarheid. ${ }^{58}$

In die gees van Nederland se 1816 Reglement, waar die band tussen belydenis en kerkregering verbreek is, ${ }^{59}$ het die Kaapse kerk ook in sy wette nie die belydenis van die kerk voor 1873 eers omskryf nie, want dit was in die staatswet genoem. ${ }^{60}$ In die 19de eeu het die Kaapse kerk aanvanklik dikwels slordige hanteerwerk met die belydenisskrifte geopenbaar. ${ }^{61}$ Só het die Transvalers op voetspoor van die Kaapse voorbeeld ook in hulle kerkwet wat in 1855 opgestel is en in 1862 verskyn het, die belydenis nie in artikel 1 genoem, soos later die geval is nie. Maar in die grondwet van die ZAR, ook in 1855 opgestel, word in artikel 20 bepaal dat die: "Nederduitsch Hervormde Godsdienstleer (dié is wat) in de jaren 1618 en 1619 door de Synode te Dordrecht is vasgesteld." ${ }^{\prime 62}$

Die ondertekeningsformulier vir predikante het in die Transvaalse eerste kerkwet ontbreek. Maar die predikante van Transvaal, $\mathrm{v} d$ Hoff, Begemann en Smits het almal, net soos Cachet self, die formulier in die Kaap onderteken waarin verklaar word dat hulle: "van harte gelooven dat de artikelen en Stukken der Leer in de Belijdenis en Catechismus" met Gods Woord ooreenkom. ${ }^{63}$ Nadat die Kaap die legitimasie in 1863 van predikante buite die sinodale verband van die Kaapse kerk ingetrek het, het die Hervormde Kerk in Transvaal in 1865 voorbereidend en in 1866 finaal ' $n$ formulier opgestel. ${ }^{64}$ In hierdie formulier word al drie die Formuliere van Eenheid genoem as "overeenkomstig Gods Woord te zijn." 65 Waar die formulier in die Kaap liberaal was soos in Nederland sedert 1816, is dit in die Kaap op Hervormingsdag 1837 weer soos in 1618/1619 te Dordrecht vasgestel. ${ }^{66}$

Die ondertekeningsformulier word as liberaal gesien wanneer dit die belydenisskrifte aanvaar in sover (quatenus) hulle met die Woord van God ooreenkom. As hulle aanvaar word omdat (quia) hulle met die Woord ooreenkom, is dit ortodoks. ${ }^{67}$ 
Soos reeds aangetoon het ook die Hervormde Kerk in Transvaal op die geleë tydstip die quia-standpunt geopenbaar. Die Transvaalse kerk sou nie deur die sameloop van bovermelde omstandighede ná die botsing met Cachet in hulle kerkwet die quia standpunt onderskryf, as dit nie hulle standpunt was nie. ${ }^{65}$ Dat daar wel huiwering was om Cachet se leerheiligheidsbeskouing na te streef, het die Hervormers gegrond gesien in artikel 7 van die Nederlandse Geloofsbelydenis, waarvolgens geen menslike geskrif aan die goddelike Skrif gelykgestel mag word nie. Dit sou na Rome lei om die Skrif in die lig van die belydenis te interpreteer ${ }^{66}$ Op 26 Februarie 1866 is die ondertekeningsformulier met quia-uitgangspunt aanvaar en dit is tot vandag in gebruik. ${ }^{67}$

Hoewel die Hervormde Kerk dus die quia standpunt handhaaf, sien hy homself as ' $n$ belydende kerk en nie ' $n$ belydeniskerk wat die belydenis gelykstel aan die Woord nie. ${ }^{68} \mathrm{By}$ ' $\mathrm{n}$ belydeniskerk is die belydenis "iets soos 'n konstitusie van 'n vereniging wat vir toelating tot lidmaatskap onderteken moet word ..." ${ }^{\prime 69}$. Cachet het later inderdaad selfs van die orrelis verwag om die Formuliere van Eenheid te onderteken. ${ }^{70}$

Die Hervormde Kerk was dus wat sy belydenis betref geensins liberaal nie. Selfs later, ná die mislukte vereniging in 1886, toe ouderling Chr Joubert hom na Holland gerig het vir'n predikant, het dr Leyds ouderling Joubert van Transvaal se "gematigd liberale" kwalifikasie vir die leraar geïnterpreteer as "tamelijk orthodox" vir Nederland. In geen geval echter mag hij een drijver zijn." ${ }^{74}$

Ds M J Goddefroy, die leraar wat aldus gevind was, het in 1890 'n geskrif die lig laat sien oor die beskuldigings teen die Hervormde Kerk van liberalisme. Daarin betoog hy, soos die titel ook aandui: "De Kerkkwestie niet een Leer - maar een Levenskwestie." 75

Die verskil tussen Cachet en die Hervormde Kerk oor die belydenis regverdig dus nie op sigself 'n afskeiding nie. Vir 'n afskeiding moes daar meerdere motiewe skuilgegaan het onder die argument van belydenis. Daarom is die $1865 / 6$ gebeure ten opsigte van die belydenis niks minder as sondige skeuring nie.

\section{Leer}

Die beskuldiging dat die Hervormde Kerk op "voetspoor volgt van de liberale Hervormde Kerk in Holland, met volkome leervryheid voor hare predikanten ..."76, hang natuurlik noú saam met die belydenis-klag.

Cachet meen om in die leer van die predikante van die Hervormde Kerk die liberale leervryheid te kan aantoon.

Op 23 Oktober 1864 sou ds Van der Hoff oor die wedergeboorte en die imago Dei gedwaal het. Die hele gebeure rondom hierdie aanklag, getuig nie van eerlike motiewe nie. ${ }^{77}$ Die verskil het daarin 
gelê dat ds van Der Hoff na aanleiding van I Petr 1:3, in ooreenstemming met sy interpretasie van die Nederlandse Geloofsbelydenis artikel XIV en die Dordtse Leerreëls III, 4, gepreek het dat daar 'n geringe oorblyfsel van die beeld van God in die mens na die sondeval is. Maar dat alleen God hierdie kiem kan opwek en ontwikkel. ${ }^{78}$ Die klaers het die standpunt ingeneem dat die mens geen aanknoping vir die genadige invloed van Gods Gees tot bekering het nie, maar soos ' $n$ stok en ' $n$ blok is. ${ }^{79}$

Dit is baie duidelik 'n kontroversiële saak, veral as Roomse, Lutherse en Metodistiese opvattings met Calvinistiese vermengd raak. ${ }^{80}$ Die beeld van God is iets wesenliks van die mens wat verlore gegaan het in die sondeval, soos waarop klaers se standpunt neerkom. Tog is die Nederlandse Geloofsbelydenis se "klein oorblyfsels" en die Dordtse Leerreëls se "enige lig" 'n spoor van die wesenlike waarop laasgenoem de deur wedergeboorte herleef.

Die Kommissie van die Algemene Kerkvergadering het op 20 Junie 1865 bevind "dat de klagers hunne aanklagt niet voldoende hebben gestaafd, en dat dus de beschuldiging is van de hand gewezen. ${ }^{81}$

Ander punte wat soms teen predikante van die Hervormde Kerk in die tweede helfte van die 19de eeu ingebring is, handel oor die predikante se hoër agting vir die Skrif as vir die belydenisskrifte. ${ }^{82}$

Verskille oor die belydenisskrifte se inhoud het ook in die destydse Kaapse Ned Gereformeerde Kerk voorgekom, byvoorbeeld oor die Dordtse Leerreëls in verband met die predestinasie en die saligheid al dan nie van alle mense. Sowel die ortodokse ds Murray as die liberale ds Kotzé het beide op sekere verskillende punte nie volledig die Dordtse Leerreëls aanvaar of geleer nie. ${ }^{83}$

Die liberale leer as sodanig is egter uit-en-uit ' $n$ verwerplike omdat dit selfs nie eens altyd die belydenis quatenus aanvaar nie; want ook die Skrif word na willekeur gehanteer. Dit blyk baie duidelik uit Sarel Celliers, ouderling van Kroonstad, wat in 1862 die Kaapse Sinode bygewoon het, se brief van landdros Comelis Bodenstein van Potchefstroom op 30 Desember $1862 .{ }^{84}$ Dis merkwaardig watter trekke van ooreenkoms daar te bespeur is tussen die destydse Liberale Teologie en ons hedendaagse Moderne Teologie. ${ }^{85}$

Van hierdie Liberale Teologie was die Voortrekkers waarlik nie te beskuldig nie. ${ }^{86}$ Daarom was die wegbreek onder Cachet in 1865/6' $n$ sondige ingreep op die liggaam van die Hervormde Kerk, onder die verskoning van besware teen liberale leervryheid.

\section{Praktyk}

Die Hervormde Kerk in Transvaal wou vry wees van die Kaapse owerheid; en wou dus ook nie onder die Kaapse Sinode ressorteer nie, aangesien laasgenoemde onder die owerheid gestaan het ${ }^{87}$ Die Transvalers was nie teen die Kaapse kerk nie, ${ }^{88}$ alhoewel die Kaapse 
kerk teen die Groot Trek was, soos die Sinode van 1837 self besluit het, en die weerhouding van predikante aan die Voortrekkers getuig. ${ }^{89}$ Omdat die Kaapse kerk sedert 1804 en veral sedert 1824 op voetspoor van Nederland se 1816 Algemeen Reglement ondergeskik aan die staat gemaak is, ${ }^{90}$, wou die Voortrekkers nooit ongedwonge die sinodale verband met die Kaap behou nie. Hierdie kerklike onderhorigheid aan die staat is op 8 November 1843 enigsins verlig en gewysig maar nie opgehef nie.91 Laasgenoemde het eers in Oktober 1957 gebeur vanweë dr J D Vorster se voorstel. ${ }^{92}$ Daarom het die Transvalers ten einde raad in 1852 voorlopig ingewillig om onder die Kaapse Sinode in te skakel om predikante te kan bekom, maar op die nippertjie dit nie deurgevoer nie omdat uitkoms uit Holland sou opdaag in 1853 - in die persoon van ds v d Hoff. ${ }^{23}$ Die Voortrekkers was mense wat wou wegkom van 'n owerheid wat hulle gegrief het. Hanekom sê: "Ons kry sedert dié tyd op Afrikaanse bodem 'n nuwe mens:

'. . die Trekkerboer

wat met sy voer

en Boek,

ver in die binneland

sy dure vryheid soek..$^{94}$

Wat die kerk as sodanig in die Kaap en die kerk as sodanig in Transvaal aanbetref, was daar geen diskontinuïteit nie. ${ }^{95}$ Wat die afwykende kerklike praktyk spesifiek van die Hervormde Kerk in Transvaal sou wees, is dus volkome ondeursigtig.

Daar word soms verwys na individuele lidmate se lewenswandel, byvoorbeeld na ds Van der Hoff, dat hy outokraties, rusiemaker, dranksugtig, ensovoorts was. ${ }^{96} \mathrm{Om}$ hierdie rede sou daar glo ook nog 'n volwaardige biografie oor ds $\mathrm{v} d$ Hoff ontbreek! ${ }^{97}$ Dat baie van hierdie aantygings onwaarhede is, is reeds bewys. ${ }^{98}$

Die kerk het steeds die tug gehandhaaf deur komende klagte op meriete te behandel. ${ }^{99}$ Cachet self sou kon getuig van baie vermanings en teregwysings wat hy hom van die Hervormde Kerk op die hals gehaal het. ${ }^{100}$

Buitendien sou Cachet nie op grond van onreëlmatige optredes van individue hóm kon skaar aan die kant van onskuldiges nie! G D Scholtz stel dat Cachet "in meer as een opsig ' $n$ man was wat dit soms moeilik gevind het om met almal oor die weg te kom." Cachet was ' $n$ man met 'n strydende gees . . ${ }^{102}$ Scholtz stel dat Cachet met sy stelling dat die Hervormde Kerk "door hare praktyk (van volkome leervryheid voor hare predikanten) de rust en welvaart van de Republiek in gevaar brengt ..."' n rede aanvoer "wat enigsins vergesog lyk en wat politiek en kerklike sake met mekaar verwar." ${ }^{103}$ Daar is oor Cachet ' $n$ oneindige lys van skeurmakende dade, eiegeregtighede, beledigings, brutaliteite, dreiginge, onwet- 
tighede, twisgierigheid, onvergenoegdheid, gemene dubbelhartigheid, minagting, belaglikheid. ${ }^{104}$ Tiperend van Cachet se optredes, is die kabaal wat hy op 22 April 1872 opgeskop het omdat die publieke aanklaer, J A Butner, teen wie hy 'n klag gelê het, volgens hom laat op kantoor gekom het. Cachet het so teen hom uitgevaar dat Butner naderhand uitgebars het: "Cachet $u$ moet nu ophouden met de grove beleedigingen en die valsche klagten, wat bliksems hebt gij altijd tegen mij te klagen." Hierop het Cachet geantwoord: "hoe durf jij zoo 'n brutaliteit te gebruiken in de straat tegen een fatsoenlijk man, ek loop niet met zoo 'n man zamen, wacht laat ik bovenkant den wind komen. ${ }^{105}$

Dat die Hervormde Kerk in praktyk so vervalle was dat dit nie hervorm kon word nie, maar dat Cachet hom daarvan moet afskei, téén die NGB artikel 27 tot 29 ín, is slegs volkome in ooreenstemming met sy gesindheid teenoor die Hervormde Kerk, en daarom is die motiewe, soos uiteengesit, dryfkragte tot sondige skeuraksies. ${ }^{106}$

In sy optrede om van plek tot plek te ry en onder bogenoemde motiewe lidmate van die Hervormde Kerk af te rokkel, het hy gebruik gemaak van bestaande politieke en kerklike woelinge. ${ }^{107}$

Cachet het soos hy op die November 1865 Algemene Kerkvergadering gedreig het, die hele land deurgereis om sogenaamde "suiwer Gereformeerde gemeenten op te richten." ${ }^{108}$ Wakkerstroom, Lydenburg, Pretoria, Potchefstroom, Hartbeesfontein, was die eerstes op sy veldtogte. ${ }^{109}$ Cachet was dikwels onwelkom. ${ }^{110}$

Op 3 Desember 1866 het Cachet te Utrecht van waar hy sy aanslag geloods het, 'n kerkvergadering gehou met 19 afgevaardigdes uit die agt groepies ${ }^{111}$ wat as gemeentetjies georganiseer is te Lydenburg, Utrecht, Nazareth, Pienaarsrivier, Heidelberg, Hartebeestfontein, Potchefstroom, en Vaalrivier. Cachet self het as voorsitter opgetree en ds Huet van Pietermaritzburg as skriba. Op 4 Desember is hierdie gemeentetjies verenig tot die Ned Gereformeerde Kerk in die Republiek. ${ }^{112}$

Los van die Gereformeerde Kerk wat in 1859 georganiseer is, los van die Ned Gereformeerde Kerk in die Kaap, en ander gebiede, en los van die Nederduitsch Hervormde Kerk, het die Ned Gereformeerde Kerk in Transvaal tot stand gekom. Omdat dit nie die produk van egte sendingwerk was nie en omdat dit ook nie teologieskerkregtelik eerbaar geskied het nie, was die afskeiding sondige verskeurdheid.

En daarom kan ek sê dat Cachet 'n verkeerdeveer-laksman was, wat 'n swaeltjie se eier uitgebroei het!

1 T N Hanekom, Ons Vaderlandse Kerkgeskiedskrywing, Rede uitgespreek by die aanvaarding van die amp van hoogleraar in die kerkhistoriese vakke aan die Teologiese Seminarium, Stellenbosch op Woensdag, 30 Maart 1960, Ned Gereformeerde Teologiese Tydskrif, Deel XVIII, Nommer 1, Januarie 1977, bladsy 38. 
2 Dr G D Scholtz, Ter Herdenking aan 4 Desember 1866, Rondom 1866, Versamel deur ds F G M du Toit, bladsy 17.

3 Prof J P Jooste, Die Geskiedenis van die Gereformeerde Kerk in Suid Afrika, 1859-1959, bladsy 194.

4 Ds F G M du Toit, Rondom 1866, bladsy 47, 91, 158, ea.

5 Prof Dr S P Engelbrecht, Geskiedenis van die Nederduitsch Heroormde Kerk van Afrika, Derde Hersiene en Vermeerderde Uitgawe, 1953, bladsy 199, 212.

AD Pont, Nicolaas Jacobus van Warmelo, 1835-1892, bladsy 67.

6 T N Hanekom, N.G.T.T., a w bladsy 78.

7 T H Hanekom, $a$ w, bladsye 78, 79.

8 C S v H Steenekamp, Die Geskiedenis van die Naamkwessie "Heroormd" en Gereformeerd," Hervormde Teologiese Studies, 9de jaargang, aflewering III en IV, Augustus 1953, bladsy 231-248.

9 Brief in Transvaal Argus, 14 Maart 1867, aangehaal by F G M du Toit, Rondom 1866, bladsy 32.

10 G D Scholtz, Ons Kerknaam, bladsy 2.

11 Ds Joh Dreyer, Hervormd as Kerknaam Gehandhaaf, bladsy 16-22.

12 Prof Dr S P Engelbrecht, Geskiedenis, bladsy 139.

13 Vergelyk G D Scholtz, Ons Kerknaam, bladsy 5, voetnoot 8.

14 C Spoelstra, Bouwstoffen voor de Geschiedenis der Nederduitsche Gereformeerde Kerk in Zuid-Afrika, (Amsterdam-Kaapstad 1906), Deel II, bladsy 256, aangehaal by G D Scholtz, Die Geskiedenis van die Nederduitse Hervormde of Gereformeerde Kerk van Suid-Afrika, 1842-1885, bladsy 7, en GD Scholtz, Ons Kerknaam, bladsy 45.

15 Dr H S Pretorius, Die Kerknaam, Byvoegsel, bladsy 1.

$16 \mathrm{~S} P$ Engelbrecht, Afdruk van die titelblad en "Approbatie" in Almanak Ned Hervormde Kerk van Afrika, 1952, bladsy 92.

17 Dreyer, Boustowwe III, bladsy 6-8, aangehaal by S P Engelbrecht, Geskiedenis, bladsy 139, en by Joh Dreyer, Hervormd, bladsy 23.

18 S P E Geskiedenis, bladsy 139.

19 G D Scholtz, Ons Kerknaam, bladsy 4.

20 Dr T W Hanekom, Die Liberale Rigting in Suid-Afrika, Eerste Deel, 1951, bladsy 50-58.

21 Ds Joh Dreyer, Hervormd, 23-28.

22 G D Scholtz, Ons Kerknaam, bladsy 6-7.

23 S P E Geskiedenis, bladsy 139: G D Scholtz, Geskiedenis, bladsy 11; Dr H S Pretorius, Die Kerknaam, bladsy 6; Ds Joh Dreyer, Hervormd, bladsy 29; S P E, Dr G D Scholtz se Geskiedenis ....., bladsy 3; G D Scholtz, My Antwoord ...., bladsy 21; S P E, Nogmaals Dr G D Scholtz, bladsy 15/16.

24 Joh Dreyer, Hervormd, bladsy 31; G D Scholtz, Ons Kerknaam, bladsy 10/11.

25 S P E Geskiedenis, bladsy 139; Joh Dreyer, a w, bladsy 32.

26 S P E, Nogmaals, bladsy 34.

27 S P E, Nogmaals, bladsy 18.

28 S P E, Nogmaals ..., bladsy 18. Vergelyk ook S P E, Geskiedenis, bladsy 139/140.

29 S P E, Nogmaals, bladsy $21 / 22$.

30 G D Scholtz, My Antwoord, bladsy 22; H S Pretorius, Die Kerknaam, bladsy 8/9.

31 S P E, Nogmaals, bladsy 17v.

32 T N Hanekom, Die Liberale Rigting, bladsy 186.

33 H S Pretorius, Die Kerknaam, bladsy 5.

34 G D Scholtz, Ons Kerknaam, bladsy 19.

35 G D Scholtz, My Antwoord, bladsy 22-24.

36 G D Scholtz, Ons Kerknaam, bladsy 17.

37 G D Scholtz, Ons Kerknaam, bladsy 19.

38 G D Scholtz, My Antwoord, bladsy 22.

39 S P Engelbrecht, Ds Frans Lion Cachet, Hervormde Teologiese Studies, Augustus 1953, bladsy 198.

40 S P E, Ds Frans Lion Cachet, a w, bladsy 200.

41 S P E, a $w$, bladsy $198 \mathrm{v}$.

A D Pont, Nederduitsch Heroormde Kerk van Afrika, Kerkgeskiedenis ten dienste van die Kategese van die Kerk, tweede gewysigde en verbeterde uitgawe, 1970, bladsy 55.

42 S P E, $a w$, bladsy 182. 
43 T N Hanekom, Die Liberale Rigting, bladsy 48.

44 T N Hanekom, Die Liberale Rigting, bladsy 50.

45 T N Hanekom, $a$, bladsy 51.

46 S P E Geskiedenis, bladsy 135.

S P E, F L Cachet, H T S, a $w$, bladsy 202.

S J Botha, Die Toetrede van Lydenburg tot die Nederduitsch Hervormde-kerkverband 1864 en die Herafskeiding onder F Lion Cachet 1866, H T S, Jaargang 20 Aflewering 3 en 4, bladsy 162 .

47 Brief aan die Uitooerende Raad, 6 Desember 1864, aangehaal by S P E, Ds Frans Lion Cachet, H T S a w, bladsy 198;

Gesprek voor die Kommissie van die Alg Kerkvergadering 26 Junie 1865, aangehaal by S P E; $a$ w, bladsy 200;

Optrede op die Algemene Vergadering van 20 November 1865, aangehaal by S P E, a $w$, bladsy 203.

Geskrif "Aan de leden der N G Kerk in de Z A Republiek, F Lion Cachet, 29 Desember 1865, aangehaal by F G M du Toit, $a$ w, bladsy 62-96.

48 F G M du Toit, $a$ w, bladsy 31 .

49 F Lion Cachet, $a w, 29$ Desember 1865, aangehaal by F G M du Toit, $a w$, bladsy 70 ; Het Volksblad, 26 April 1866, aangehaal by F G M du T a $w$, bladsy 149; H S Pretorius, a $w$, bladsy 12; G D Scholtz, Ons Kerknaam, bladsy 20; G D Scholtz, My Antwoord, bladsy 23; S P E, Nogmaals, bladsy 19; Joh Dreyer, Heroormd, bladsy 6, $39-43$.

50 F L Cachet, a $w$, bladsy 70.

51 S P E, Nogmaals, bladsy 7-9.

52 A D W Wolmarans, Kerkhistoriese Feiten, bladsy 9.

53 S P E, Geskiedenis, bladsy 210.

54 F G M du T, $a$ w, bladsy 31, 78, 87-92.

55 S P E, Geskiedenis, bladsy 211.

F G M du T, $a$ w, bladsy $71 v$.

56 F G M du T, $a w$, bladsy 92.

57 F G M du T, $a w$, bladsy 95.

S P E, Dr GD Scholtz, bladsy 18.

G D Scholtz, My Antwoord, bladsy 40.

58 T N Hanekom, Die Liberale Rigting in Suid Afrika.

59 T N Hanekom, $a w$, bladsy $179,310 / 311$.

60 S P E, Geskiedenis, bladsy 214.

61 T N Hanekom, $a$, bladsy 312 en voetnoot 1 .

A D Pont, Enkele Aantekeninge by die debat oor die uitleg van die Dordtse Leerreëls wat in 1871 deur Ds JJ Kotzé van Darling en Ds Andrew Murray, Jnr, gevoer is, H T S, April 1959 , bladsy 30, voetnoot 10 .

62 S P E, Geskiedenis, bladsy $212 v$.

63 S P E, F L Cachet, H T S, a w, bladsy 201; S P E, Geskiedenis, bladsy 213.

64 S P E, Geskiedenis, bladsy 213-214.

65 S P E, a $w$, bladsy 214.

66 T N Hanekom, $a$ w, bladsy 185-187.

67 T N Hanekom, $a w$, bladsy 185.

F G M du Toit, $a$ w, bladsy 116.

68 G D Scholtz, My Antwoord, bladsy 40.

S P E, Geskiedenis, bladsy 214.

69 A D Pont, N J $v$ Warmelo, bladsy 72.

S P E, Geskiedenis, bladsy 215.

70 S P E, Geskiedenis, bladsy 214.

S P E, Geskiedenis, bladsy 215.

71 A D Pont, $a w$, bladsy 73.

Joh Dreyer, Belydenis en nie Belydende Kerk nie?, Die Hervormer, Maart 1957, bladsy 6.

72 Joh Dreyer, Nie Doel nie maar Middel, Die Hervormer, Februarie 1960. S P Engelbrecht, Neo-Calvinisme, Ontwikkeling of Afwyking, 1945, bladsy 81.

73 S P E, F L Cachet, H T S a $w$, bladsy 230.

74 G D Scholtz, My Antwoord, bladsy 40. S P E, Nogmaals, bladsy 53-56.

75 S P E, a w, bladsy 55. 
76 F G M du T, $a$ w, bladsy 92.

77 G D Scholtz, Geskiedenis, bladsy 199.

G D Scholtz, My Antwoord, bladsy 45.

S P Engelbrecht, Die Konflik in die Gemeente Wakkerstroom (Volksrust), Almanak, Ned Herv Kerk, 1941, bladsy 85v.

S P Engelbrecht, Die Nederduitsch Hervormde Gemeente Volksrust (Wakkerstroom) 1861-1941, bladsy 8.

78 S P E, Almanak, 1941, bladsy 91.

79 S P E, Almanak, 1941, bladsy 92.

80 S P E, Almanak, 1941, bladsy $90,92$.

81 S P E, Almanak, 1941, bladsy 98.

82 G D Scholtz, Geskiedenis, bladsy 200-201.

83 A D Pont, a w, H T S April 1959, bladsy 29-38.

Vergelyk T N Hanekom, Liberale Rigting, bladsy 430.

84 T N Hanekom, $a w$, bladsy 441-475.

85 Dr D J Smith, Die Nuwe Teologie - Alleen negatief of ook positief te beoordeel?, H T S. jaargang 32, aflewering 3 en 4, bladsy 181-191.

Prof L Floor, Die neo-marxisme in die moderne teologie en ons antwoord daarop, In die Skriflig, Tydskrif van die Gereformeerde Teologiese Vereniging, jaargang $10 \mathrm{nr} 39$, Sept 1976, bladsy 17-27.

86 A D Pont, $N$ J $v$ Warmelo, bladsy 78.

87 S P E, Geskiedenis, bladsy 84.

88 T N Hanekom, $a w$, bladsy 383.

89 T N Hanekom, $a$ w, bladsy $389,468,176,382$.

90 T N Hanekom, $a w$, bladsy 310 .

91 T N Hanekom, $a w$, bladsy 313.

92 S P E, Nogmaals, bladsy 28/9.

93 S P E, Nogmaals, bladsy 32-46.

94 T N Hanekom, $a w$, bladsy 382.

95 A D Pont, Die Kontrovers tussen prof S P Engelbrecht en Dr G D Scholtz, Lesing gehou voor die Historiese Vereniging van die Universiteit van Pretoria, op Woensdag, 21 Mei 1958.

96 G D Scholtz, Geskiedenis, bladsy 173v.

G D Scholtz, My Antwoord, bladsy 44-46.

A D Pont, Rondom die figuur van ds Dirk $v d$ Hoff, H T S, jaargang 30, aflewering 3 en 4 , bladsy 168 .

97 G D Scholtz, My Antwoord, bladsy 48.

98 S P E, Nogmaals, bladsy 58v.

99 S P E, Almanak, 1941, bladsy 98.

G D Scholtz, Geskiedenis, bladsy 174.

100 S P E, F L Cachet, H T S a $w$, bladsy 205.

F G M du Toit, $a$ w, bladsy 91, punt 1 .

101 G D Scholtz, Geskiedenis, a $w$, bladsy 190.

102 G D Scholtz, $a w$, bladsy 209.

103 G D Scholtz, $a$ w, bladsy 198.

104 S P E, F L Cachet, H T S, a w, bladsy 181-231.

Vergelyk ook die Kaapse advokaat C J Brand, vader van die latere Vrystaatse president J H Brand, se brief op 31 Januarie 1854 aan die Transvaalse Volksraad, aangehaal by $S$ P E, Nogmaals, bladsy 45.

105 S P E, F L Cachet, H T S, a w, bladsy 218.

106 S P Engelbrecht, Die Nederduitsch Heroormde Gemeente Pretoria 1855-1955, bladsy 32.

A D Pont, Ds Dirk van der Hoff, H S V Bladsy 76, bladsy 3.

S P E, Geskiedenis, bladsy 217.

107 S P E, Geskiedenis, bladsy 100v, 105v, 187v, 191v.

S J Botha, Die Afskeiding onder Wessel Badenhorst oan die Heroormde Gemeente Potchefstroom in 1853 en die toetrede van Hartbeesfontein as 'n Afsonderlike Gemeente van die Nederduitsch Heroormde Kerk in 1866, H T S, jaargang 22, aflewering 4, bladsy $177 \mathrm{v}$.

S J Botha, Die Toetrede van Lydenburg tot die Nederduitsch Hervormde-Kerkverband 1864 en die Herafskeiding onder F Lion Cachet 1866, H T S, jaargang 20, aflewering 3 en 4, bladsy $162 v$. 
108 S P E, Geskiedenis, bladsy 215.

109 S P E, Geskiedenis, bladsy $217 \mathrm{v}$.

S J Botha, Die Afskeiding onder Wessel Badenhorst . . H T S, a w, bladsy 195/6.

110 F G M du Toit, a $w$, bladsy 119.

S P Engelbrecht, Die Nederduitsch Heroormde Gemeente Zeerust (Mariko) 1871-1946, bladsy 12 .

111 S P E, F L Cachet, H T S $a$ w, bladsy 207.

112 F G M du Toit, $a w$, bladsy 120 . 